\title{
Transfer of undertakings: content and structure of the TUPE Regulations 2006
}

by John McMullen

The author explains the content and structure of the new TUPE Regulations 2006 and considers the impact of two important decisions on transfer law, one in the Employment Appeal Tribunal and one in the European Court of Justice.

$\mathrm{T}$ he long awaited Transfer of Undertakings (Protection of Employment) Regulations 2006 were laid before Parliament on February 7, 2006 and came into force on April 6, 2006. They are known as the Transfer of Undertakings (Protection of Employment) Regulations 2006 (SI 2006/246) and replace the Transfer of Undertakings (Protection of Employment) Regulations 1981 (SI 1981/1794). We analyse these new provisions and also take the opportunity of highlighting two important new cases decided before the new Regulations came into effect, but which nonetheless apply in the interpretation of the 2006 Regulations, namely Sweetin V Coral Racing (EAT(s) 0039/05) in the Employment Appeal Tribunal, on the quantum of award to be made for breach of the information and consultation provisions of the Regulations, and the European Court's decision in Hans Werhof $v$ Freeway Traffic Systems GmbH \& Co KG (Case C499104) on the survival of collective bargaining arrangements following a transfer of an undertaking.

\section{INTRODUCTION}

It is common ground amongst UK employment lawyers that the law in Britain implementing the EC Acquired Rights Directive 2001/23, the Transfer of Undertakings (Protection of Employment) Regulations 1981 ("TUPE"), badly needed amending. The UK Government had to implement the Acquired Rights Directive 98/50, which amended Directive $77 / 187$, both of which are now consolidated in Directive 2001/23. Directive 98/50 should have been transposed into EU Member States' domestic legislation by July 17, 2001. In addition to the imperative to implement EU law, the British government also seeks to tackle a number of areas that are causing difficulties in practice in the UK. The principal concern is the application of TUPE and the Acquired Rights Directive to outsourcing.

The government's policy aims in its reforms are to improve business flexibility by extending coverage of
TUPE in service contracting situations, such as cleaning, security and maintenance services, so as to make it clearer that TUPE applies in such situations; to increase the transparency of the transfer process by introducing a requirement on the old employer to notify the new employer of employment liabilities; to clarify the circumstances in which employers can lawfully make transfer-related dismissals and agree transfer-related changes to employment conditions; and, finally, to take the option in Directive 98/50 for more flexibility in the application of TUPE to insolvency disposals to give a boost to the "rescue culture".

On March 15, 2005 the UK Department of Trade and Industry published its long awaited public consultation document on draft revised TUPE Regulations. The final Regulations (The Transfer of Undertakings (Protection of Employment) Regulations 2006 (SI 2006 No 246)) came into force on April 6, 2006. They differ slightly from the draft proposals, published in March 2005. Where a change was made, the reader's attention is drawn to this in discussing the final, 2006, Regulations.

\section{REGULATION 3 AND THE TRANSFER DEFINITION}

An analysis of Regulation 3 may conveniently be divided into three parts, namely, public sector transfers, the "standard" definition of a transfer and the "extended" definition of a transfer applicable only to service provision changeovers.

\section{Public sector transfers and transfers within public administration}

Regulation 3(4)(a) confirms that new TUPE applies to "public and private undertakings engaged in economic activities whether or not they are operating for gain". However, Regulation 3(5) provides that "an administrative reorganisation of public administrative authorities or the 
transfer of administrative functions between public administrative authorities is not a relevant transfer". The regulations here implement the provisions of Article 1(c) of Directive 2001/23.

\section{The "standard" transfer definition}

The "standard" definition of a transfer is contained in Regulation 3(1)(a), which applies the regulations to "a transfer of an undertaking, business or part of an undertaking or business situated immediately before the transfer in the United Kingdom to another person where there is a transfer of an economic entity which retains its identity". For this purpose, "economic entity" is defined, in Regulation 3(2), as "an organised grouping of resources which has the objective of pursuing an economic activity, whether or not that activity is central or ancillary". In this regard the regulations implement Article 1(b) of Directive 2001/23, which is declaratory of ECJ case law on the subject. One significant point to note is the retention of the requirement, in the new TUPE Regulations (see also Directive 2001/23), that there be a change of employer. Acquisitions of companies by share sales will therefore continue to be excluded from TUPE.

\section{The "extended" transfer definition - service provision changeovers}

Many putative transfers will continue to be governed solely by the "standard" transfer definition. But service provision changeovers are given preferential treatment, for they are governed also by what may be described as an "extended" definition of a transfer, which exceeds the protection given to workers by Directive 2001/23. This is a supplementary definition: if a putative transfer does not meet the test in the "extended" definition, it may still pass as a TUPE transfer if it nonetheless qualifies under the "standard" definition.

At first, the supplementary definition of a transfer under Regulation 3(1)(b) on service provision change appears simple - as long as service activities cease by one person (transferor) and are taken up by a new person (transferee) and, prior to the changeover, there was an organised grouping of employees, the principal purpose of which was to carry out those activities, there will be a transfer. This is in contrast with the requirements under the general law (and the "standard" definition) as laid down by the ECJ decision in Ayse Süzen v Zehnacker Gebaudereinigung GmbH Krankenhausservice [1997] IRLR 255. In Süzen it was stressed that a mere changeover of contractors is not a transfer - what is required is a concomitant transfer of assets or a taking over of a major part of the workforce. Regulation 3(1)(b), it is to be noted, covers client to contractor, contractor to contractor and contractor to client changeovers.

But this new definition is qualified by two exceptions. First, it will not apply if the client intends that the activities will be carried out, following the service provision change, in connection with a single specific event or task of short term duration (Reg 3(3)(a)(ii)). So a conference project, for example, would be excluded. And this is so even if the client uses the contractor again. For, as the consultation document states (para 24, p 17), this may be fortuitous it may still not be intended that there be an ongoing relationship. Secondly, the new definition does not apply where the activities concerned consist wholly or mainly of the supply of goods for the client's use (Reg 3(3)(b)).

Procurement of professional services was originally proposed also to be excepted, but this exemption was dropped from the final version.

\section{CHANGES TO EMPLOYMENT TERMS AND CONDITIONS}

The ability of an employer to vary employment terms before or after a TUPE transfer is heavily circumscribed, even where the employee consents to such change. Under Community law, an employee may not waive rights granted to him under Directive 2001/23 (see Foreningen af Arbejdsledere I Danmark v Daddy's Dance Hall A/S [1988] IRLR 315).

In new TUPE it is provided that a purported variation will be void if the "sole" or "principal" reason is either (1) the transfer itself or (2) a reason connected with the transfer that is not an economic, technical or organisational reason entailing changes in the workplace (Reg 4(4)). On the other hand, an employer and an employee may agree on a variation if the sole or principal reason for the variation is (1) a reason connected with the transfer that is an economic, technical or organisational reason entailing changes in the workforce or (2) a reason unconnected with the transfer (Regulation 4(5)). The problem with the variation permitted under (1) above is that Daddy's Dance Hall does not expressly allow for variations which are for an economic, technical or organisational (ETO) reason. It appears to invalidate variations which are "by reason" of the transfer. However, the government regards it as illogical to permit dismissals for an ETO (provided for initially in Reg 8(2) of the TUPE Regulations 1981 and now in Reg 7 of the TUPE Regulations 2006 - see below), but not variations of contract. In practice, however, this change may be more limited than appears at first glance. A variation for a reason connected with the transfer may only be justified by an ETO if the ETO also entails a change in the workforce. This significantly limits the apparent flexibility given to employers by the new regulation since relatively few contract changes will involve such a change in the actual composition of the workforce. 


\section{CLAIMS ARISING OUT OF EMPLOYER- INITIATED CHANGES TO WORKING CONDITIONS}

A feature of the TUPE Regulations 2006 is a new claim, in Regulation 4(9), where there is a substantial change in working conditions to the material detriment of an employee whose contract is transferred under TUPE. In such a case the employee may treat the contract of employment as having been terminated and the employee may treat himself as having been dismissed. It is important to note that this claim does not depend on an employer's fundamental breach of contract. An employee, by virtue of Regulation 4(10), may not claim damages by reason of any failure by the employer to pay wages to an employee in respect of a notice period which the employee has failed to work if this claim arises. But a claim for constructive unfair dismissal would apply. The new claim under Regulation 4(9) is without prejudice to the right of an employee arising apart from the Regulations to terminate the employment contract without notice and acceptance of a repudiatory breach of contract by the employer. It is believed that Regulation 4(9) will lead to a new raft of claims based on changes in working conditions short of an employer's actual breach of contract.

\section{TRANSFER-CONNECTED DISMISSALS}

A new Regulation 7 is intended to implement the government's wish to clarify the existing Regulation 8 of the 1981 Regulations. Under Regulation 7(1), where either before or after the transfer, an employee of the transferor or transferee is dismissed, the employee is automatically unfairly dismissed if the sole or principal reason for the dismissal is (1) the transfer itself or (2) a reason connected with it that is not an economic, technical or organisational reason entailing changes in the workforce. Where there is an economic, technical or organisational reason entailing changes in the workforce, Regulation 7(1) ceases to apply, and the dismissal is not automatically unfair (see Regulation 7(2)).

\section{PENSIONS}

Article 4(a) of the Acquired Rights Directive 2001/23 exempts from transfer rights under supplementary company or intercompany pension schemes that relate to employees' rights to old-age, invalidity or survivors' benefits "unless Member States provide otherwise" (emphasis added). Under Regulation 10 of the Regulations, however, such provisions of an occupational pension scheme (as defined by the Pension Schemes Act 1993 (as amended) or the Social Security Pensions (Northern Ireland) Order 1975) are still excluded from transfer under Regulations 4 and 5 of the new regulations, as was the case under Regulation 7 of the TUPE Regulations 1981. However, it is expressly provided (Reg 10(2)) that provisions relating otherwise than to old-age, invalidity or survivors' benefits are not treated as being part of the scheme, and are therefore liable to transfer under Regulations 4 and 5. The government has therefore not taken the option in Directive $2001 / 23$ to impose wholesale transfer of pension obligations from transferor to transferee. Instead, it has created a more modest obligation on transferees to make pension provision under the Pensions Act 2004, by the Transfer of Employment (Pension Protection) Regulations 2005, which have been in force since April 2005.

\section{INSOLVENCY}

The insolvency provisions of the draft Regulations are contained in Regulations 8 and 9.

The new regulations provide that Regulations 4 (transfer of employment obligations) and 7 (protection against dismissal) do not apply where the transferor is the subject of bankruptcy proceedings or any analogous proceedings which have been instituted with a view to the liquidation of the assets of the transferor and are under the supervision of an insolvency practitioner.

Directive 98/50 (now Directive 2001/23) offered Member States the option however to relax the provisions of the directive on applicable insolvency proceedings covered by the Directive in two important respects - by allowing non-transfer of certain debts from transferor to transferee (provided employees are adequately safeguarded (see Art 5(2)(a)) and allowing alterations to employment contracts via employee representatives designed to safeguard employment opportunities by ensuring the survival of the undertaking (Art 5(2)(b)).

The regulations take up both these options. Regulation 8 prevents the operation of Regulation 4 to transfer liability for unpaid sums due to transferring employees, provided these are sums reimbursable by the secretary of state as identified in the "relevant statutory schemes" (ie Chapter VI of Part XI of the ERA 1996 and Part XII of the ERA 1996, and the equivalent Northern Ireland legislation).

Regulation 9 allows the transferor or transferee (or an insolvency practitioner) to agree to certain permitted variations to employment contracts via "appropriate employee representatives". Appropriate representatives are, in keeping with other employment legislation, recognised trade union representatives or, in any other case, elected or appointed employee representatives.

The permitted variation to employment contracts, in accordance with Article 5(2)(b) of the directive, is one that is designed to safeguard employment opportunities by ensuring the survival of the undertaking, business or part of the business the subject of the relevant transfer (variations which are connected with the transfer but are for an economic, technical or organisational reason entailing changes in the workforce are in any event permitted in insolvency or otherwise by Regulation 4(5)(a), which is unaffected by these provisions). 


\section{NOTIFICATION OF EMPLOYEE LIABILITY INFORMATION}

Article 3(2) of Directive 2001/23 allows Member States to oblige a transferor to notify a transferee of employment rights and obligations. Regulation 11 implements this option, which will be of especial use in contractor changeover cases (where it can be difficult for an incoming contractor to obtain information from an outgoing contractor as there is no contractual nexus or bargaining leverage between them). The required employment information is specified in Regulation 11(2). Employee liability information must be delivered to the transferee by the transferor not later than 14 days before the relevant transfer. A complaint of failure to notify employee liability information may be made against a transferor by a transferee before an employment tribunal. Compensation is such as is just and equitable and is subject to a minimum of $£ 500$ per employee in respect of whom the transferor has failed to comply concerning the supply of employee liability information. In assessing compensation a tribunal has to have regard to the loss sustained by the transferee and the terms of any contract between the transferor and the transferee relating to the transfer under which the transferor may be liable to pay any sum to the transferee in respect of a failure to notify the transferee of employee liability information.

\section{JOINT AND SEVERAL LIABILITY}

Directive 2001/23 gives Member States the option of incorporation of joint and several liability in respect of obligations which, apart from such provision, would fall exclusively on the transferee (see Art 3(1)). The Regulations take up this option in two areas. The first is in respect of liability under Regulation 15 for failure to inform and consult appropriate employee representatives under Regulation 13 of the regulations (see Reg 15(9). The second area concerns liability for personal injury in cases where a transferor employer (eg, in the public sector) is not obliged to carry employer's insurance under the Employer's Liability (Compulsory Insurance) Act 1969). Here, again, under Regulation 17(2), the transferor and transferee are held jointly and severally liable in respect of personal injury liability arising from the employee's employment with the transferor.

\section{THE TEST FOR ASSESSING AN AWARD FOR FAILURE TO INFORM AND CONSULT UNDER THE TUPE REGULATIONS}

In Sweetin v Coral Racing (EAT(S)/0039/05) the claimant, Mrs Sweetin, sought compensation for unfair constructive dismissal and failure to consult prior to a TUPE transfer of a bookmakers business in which she was employed. The claim for constructive dismissal failed before the employment tribunal and the EAT declined to interfere with the ruling on this point. Sweetin's secondary claim however was in relation to her employer's failure to inform and consult pursuant to Regulation 10 of TUPE 1981 (now Regs 13 to 16 of TUPE 2006). It is this particular aspect of the case that we report.

Sweetin was an employee of Toal's bookmakers, based in Ireland. She was based in the company's Stranraer outlet. In September 2003 Toal's business in Stranraer was transferred to Coral Racing. She left following a grievance against her employers and, as stated, her subsequent constructive unfair dismissal claim failed on the facts. The employment tribunal found, however, that there had been a failure by the employer to inform and consult under TUPE. The tribunal fixed the sum payable under Regulation 11 of TUPE 1981 as the equivalent of six weeks' pay. On the appeal on the amount of compensation payable for failure to inform and consult, the EAT ruled that the employment tribunal had applied the wrong approach in assessing the appropriate sum to award by taken account of the extent of the claimant's loss. It considered that the appropriate award to the category of affected employees was six weeks' wages bearing in mind the amount of time actually taken by the company to resolve matters relating to terms and conditions of employment of transferring employees and estimated that the amount of time proper negotiations would have taken would have been about six weeks. This was notwithstanding the tribunal's categorisation of the failure to consult as having been "serious" and "gross".

In Susie Radin the Court of Appeal suggested the following guidelines in assessing the amount of the protective award under section 188 of the Trade Union and Labour Relations (Consolidation) Act 1992 for failure to inform and consult in advance of multiple redundancies. Lord Justice Peter Gibson stated:

"(1) The purpose of the award is to provide a sanction for breach by the employer of the obligations in section 188 : it is not to compensate the employees for loss which they have suffered in consequence of the breach.

(2) The employment tribunal has a wide discretion to do what is just and equitable in the circumstances, but the focus should be on the seriousness of the employer's default.

(3) The default may vary in seriousness from the technical to a complete failure to provide any of the required information and consult.

(4) The deliberateness of the failure may be relevant, as may be the availability to the employer of legal advice about his obligation under section 188.

(5) How the employment tribunal assesses the length of the protective period is a matter for the employment tribunal but a proper approach in a case where there has been no consultation is to start with the maximum period and reduce it only if there are mitigating circumstances justifying a reduction to an extent which the employment tribunal considers appropriate". 
The EAT in Sweetin considered that Parliament could not have intended any different approach to the assessment of compensation under TUPE, compared with the redundancy provisions of the 1992 Act and, accordingly, the Susie Radin guidelines should be applied in assessing the award to be made for failure to inform and consult under TUPE. In this case, therefore, the tribunal's award of six weeks' pay was overturned and an order of 13 weeks' pay (the maximum) substituted. This case of course applies fully to the interpretation of Regulations 13 to 16 of the TUPE Regulations 2006.

\section{AN EMPLOYER'S RESPONSIBILITY UNDER THE ACQUIRED RIGHTS DIRECTIVE FOR COLLECTIVE AGREEMENTS CONCLUDED AFTER THE DATE OF THE TRANSFER}

In Hans Werhof v Freeway Traffic Systems GmbH \& Co KG (Case C-499/04) the European Court considered, for the purpose of interpreting Directive 2001/23, whether an employer was bound by a collective agreement concluded by an employer's organisation which succeeded the collective agreement in force concerning transferring employees at the time of the transfer.

This case was a reference for a preliminary ruling from the Landesarbeitsgericht Düsseldorf, Germany. Mr Werhof began work for DUEWAG AG on April 1, 1985, initially on a temporary basis but, from September 1, 1985, on a permanent basis. It was agreed that the employment relationship would be governed by the framework collective agreement and the wage agreement in force at the material time for workers in the North RhineWestphalia metal and electrical industry negotiated between the Industriegewerkschaft Metall (Trade Union for the Metal Industry) (of which the employee, incidentally was not a member when he was first employed) and the Verband der Metall - und Elektroindustrie Nordrhein-Westfalen Metal and Electrical Industry Federation, North Rhine-Westphalia (the Employers' Federation) of which the employer was a member.

On April 1, 1999 the company was changed into Siemens DUEWAG GmbH and, some months later, transferred part of its business in Düsseldorf in which $\mathrm{Mr}$ Werhof was employed to Freeway Traffic Systems GmbH \& Co KG which is not a member of the Employers' Federation that concludes collective agreements for employers in the industry. As part of the transfer $\mathrm{Mr}$ Werhof's employment relationship was also transferred. On August 2, 2001 the new owner agreed with the works council a grid for the grading of employees on the basis of the collectively agreed provisions in force in the North Rhine-Westphalia metal and electrical industry. On August 13, 2001 the employer agreed a single payment for staff in return for which the employee signed a document waiving all individual claims that might subsist to standard wage increases relating to previous periods. The company concluded a supplement to his employment contract about his salary.

Meanwhile, the union and the federation concluded a new collective agreement on May 23, 2002 which provided for an increase in the wage of $2.6 \%$ and a further additional payment from June 1, 2003. Mr Werhof therefore brought legal proceedings claiming that, with effect from June 1, 2003 he should be entitled to payment of the difference between the sums he had received and those ostensibly owing to him under the new agreement. The Landesarbeitsgericht Düsseldorf stayed the proceedings and referred the following questions to the court for a preliminary ruling:

"(1) Is it compatible with Article 3(1) of Council Directive 98/50/EC of 29 June 1998 amending Directive

$77 / 187 / E E C$ on the approximation of the laws of the Member States relating to the safeguarding of employees' rights in the event of transfers of undertakings, businesses or parts of businesses if a transferee of a business - who is not subject to a collective agreement - is bound by an agreement between the transferor of the business - who is subject to a collective agreement - and the employee, under which the collective wage agreements concluded by the transferor are to apply, in such a way that the collective wage agreement in force at the time of the transfer of the business applies but collective agreements entering into force subsequently do not?

(2) If that is to be answered in the negative:

Is it compatible with Article 3(1) of Directive 98/50/EC if the transferee of the business is bound by collective wage agreements which have entered into force after the transfer of the business only so long as the transferor of the business is so bound?"

On November 152005 Advocate-General Ruiz-Jarabo Colomer ruled as follows on the first only of these questions:-

"Where a worker's contract of employment refers to a collective agreement binding on the transferor of a company, it is not contrary to Article 3(1) of Council Directive 77/187/EEC of 14th February 1977 on the approximation of the laws of the Member States relating to the safeguarding of employees' rights in the event of transfers of undertakings, businesses or parts of businesses, if the transferee, who is not a member of an Employers' Federation which negotiates such agreements, does not apply those which have replaced the one which was in force at the time of change of ownership".

The European Court agreed, and on March 9, 2006 ruled:

"Article 3(1) of Council Directive 77/187/EEC of 14 February 1977 on the approximation of the laws of the Member States relating to the safeguarding of employees' rights in the event of transfers of undertakings, businesses or parts of businesses must be interpreted as not precluding, in a 
situation where the contract of employment refers to a collective agreement binding the transferor, that the transferee, who is not a party to such an agreement, is not bound by collective agreement subsequent to the one that was in force at the time of the transfer of the business".

The competing arguments here were as follows. The claimant argued that the term in his employment contract referring to collective agreements concluded in the sector must necessarily be "dynamic" and so it could refer to collective agreements concluded after the date of transfer. The employer however argued that the clause was "static" in nature that is to say only the collective agreement in force at the time of transfer was applicable. The court agreed with the employer and held that a clause referring to a collective agreement on transfer could not have a wider scope than the agreement to which it referred. As the Directive itself states in relation to collective agreements, terms and conditions under the transferring collective agreement are to continue to be observed only until the date of its termination or expiry or the entry into force or application of another collective agreement. The interpretation contended for by the claimant could therefore not be accepted. According to the court the wording of the Directive did not indicate that the Community legislator intended that the transferee would be bound by collective agreements other than the one in force at the time of the transfer.

Another powerful argument in favour of the employer was that the employer's right of freedom of association must be respected. This included the right not to join an association or trade federation. If the dynamic interpretation contended for by the claimant were applied it would mean that future collective agreements applied to a transferee who was not a party to a collective agreement and his fundamental right not to join an association would be detrimentally affected.

Dr John McMullen

Partner and Head of Employment Law at Watson Burton LLP

(www.watsonburton.com) and Professor of Labour Law at the University of

Leeds. He is author of the leading work on business transfers, Business

Transfers and Employee Rights (LexisNexis Butterworths, looseleaf

service and bulletins).

\section{IALS Events}

Monday, 2 October, 6-7.30pm

IALS - Law Commission discussion evening

\section{STUART BRIDGE}

Law Commissioner for England \& Wales

\section{JO MILES}

Lawyer, Law Commission Property, Family and Trust Team

\section{REBECCA PROBERT}

School of Law, University of Warwick

Cohabitation: the financial consequences of relationship breakdown In August 2005, the Law Commission began work on a project considering the law relating to property and finances that applies to cohabiting couples on the termination of their relationships by separation or death. In May 2006, the Commission published a consultation paper, setting out some provisional proposals and inviting comments on a possible new scheme of financial relief on separation. It also made provisional proposals regarding amendments to the existing law of family provision on death, and regarding agreements whereby couples who wished to do so could "opt out" of any new scheme, and make their own provision. This discussion evening will provide an outline of the proposed scheme and the principles underlying it, and invite comment on issues raised in the consultation paper.
Thursday 5 October, 6-7pm

\section{STEPHEN MASON}

Associate Senior Research Fellow, IALS; Director of the Digital Evidence Research Programme, BIICL

Proving intent in the digital environment

The above events are free, and will be held at the Institute of Advanced Legal Studies, Charles Clore House, 17 Russell Square, London WC1B 5DR. CPD accreditation with the Law Society and the Bar Council is provided with many of our events. Those requiring CPD accreditation must register on arrival. Anyone wishing to attend should contact Belinda Crothers at the IALS (email: IALS.Events@sas.ac.uk). 